\title{
ПРОБЛЕМА СЦЕНІЧНОЇ КУЛЬТУРИ В АМАТОРСЬКОМУ КОЛЕКТИВІ ТЕАТРУ
}

Художня творчість невіддільна від духовного обличчя самого художника - письменника, артиста, музиканта, скульптора, живописия, актора. Великий художник тим і великий, щчо в його творах відбилося життя у всій його глибині, в нескінченному різноманітті його проявів. Для того щяоб наблизитися у своїй творчості до величин, необхідно вивчити природні закони і навчитися свідомо користуватися ними, застосовувати у власній творчій практиці. Основний закон будь-якої художньої творчості говорить: мистеитво - відображення $i$ пізнання життя; не знаючи життя, творити не можна. Абсолютно марно намагатися підняти культуру та етику колективу на належну висоту на основі старих, застиглих норм, які пройшли тисячі разів, потрібно створювати нові норми. Питання про культуру в студї-завдання не дисциплінарне, а творче. У цій галузі потрібно все переглянути і вибудувати наново. Актор повинен сприймати будь-який об' єкт таким, яким він реально йому даний, ставитися ж до иьього об' єкта він повинен так, як йому задано. Це творче перетворення навколишнього середовища і всього, щчо відбувається на сцені, актор здійснює за допомогою своєї творчої віри в правду вимислу, а творча віра видобувається за допомогою фантазії, щзо поставляє необхідні сценічні виправдання. Для того щзоб виявити особливості та проблеми сценічної культури молодого театрального колективу, був проведений аналіз теоретичних матеріалів, щуо стосуються такої тематики. Автори дійшли висновку, щчо одним з основних аспектів сиенічної культури та поведінки актора є питання уваги на сиені. Навіть найпростіші вправи на увагу (особливо ті, які пов'язані з внутрішньою зосередженістю) дають матеріал для того, щуоб судити не тільки про особливості і характер уваги молодого актора, а й про особливості його мислення, про характер його фантазії $i$, нарешті, навіть про ідейну спрямованість його інтересів. Що ж стосується вправ на виправдання і на зміну відносин, то тут розкриваються найширші можливості для осягнення внутрішнього світу і творчих особливостей акторів-аматорів. Аби правильно розподіляти ії, важливо знати певні методи роботи з акторами.

Ключові слова: театральне мистеитво, акторська робота, поведінка на сиені, аматорський театр.

Taras HARAHONYCH, orcid.org/0000-0002-7716-2361 Honored Worker of Ukraine Culture, Senior Lecturer at the Department of Artistic Disciplines Uzhhorod Institute of Culture and Arts (Uzhhorod, Ukraine) t.harahonych@uohk.com.cn

Kateryna HLIUDZYK, orcid.org/0000-0002-3920-1198 Student Uzhhorod Institute of Culture and Arts (Uzhhorod,Ukraine) kate.gl@tanu.pro

\section{THE PROBLEM OF STAGE CULTURE IN THE AMATEUR THEATRE ENSEMBLE}

Artistic creativity is inseparable from the spiritual face of the very artist - writer, musician, sculptor, painter, actor. The greatness of an artist is determined by their works, which reflect the artist's life in all its depth, in the infinite variety of its manifestations. To approach the such greatness, it is necessary for the artist to study the laws of nature and learn to consciously use them, to apply them in creative practice. The fundamental law of all artistic creativity says: art imitates 
life; without knowing life, one cannot create. It is absolutely useless to try to raise the culture and ethics of the ensemble to the proper height based on the obsolete norms, hence it is necessary to create new norms. The question of culture in the studio is not a disciplinary task, but a creative one. Everything needs to be reviewed and rebuilt in this area. The actor must perceive any object as it is actually given to him, and he must treat this object as he was instructed to. The actor carries out this creative transformation of the environment and everything that happens on stage with his creative faith in the truth of fiction, and creative faith is extracted through imagination, which provides the necessary stage acts. To identify the features and problems of the stage culture of the young theatre group, the theoretical materials related to this subject were analyzed. The authors concluded that one of the main aspects of stage culture and behaviour of the actor is the issue of attention on stage. Even the simplest attention exercises (especially those related to inner concentration) provide material to judge not only on the features and nature of the young actor's attention, but also the peculiarities of his thinking, the nature of his imagination and, finally, even on the ideological orientation of his interests. As for the exercises to justify and change attitudes, it opens up the widest opportunities for understanding the inner world and creative features of amateur actors. To properly distribute it, it is important to know certain methods of working with actors.

Key words: theatrical art, acting, behaviour on stage, amateur theatre.

Постановка проблеми. Аматорські театральні практики різноманітні, і групи (деякі швидкоплинні, деякі живуть довго, які збираються разом, щоб створювати театр у будь-якому місці і в будьякий час) переслідують зовсім різні цілі. Таким чином, виявлення складності того, що може означати «аматорський» як культурна практика, залежить від розташування аматорських культурних практик стосовно мереж культурних інститутів, форм, національної культурної політики і традицій. Вивчаючи різноманітну історію аматорського театру в різних національних державах, можна виділити три лінії аматорського театру (Слуцкая, 2019: 160-161; Басалаев, 2018: 50-53). Одна точка зору простежує аматорський театр як місце для авангардних інновацій і політично стійких форм, тоді як інша визначає аматорські театральні групи як консервативну культурну силу, естетично і політично традиційну, зосереджену на питаннях вдосконалення або освіти. Третя історія участі любителів зазначає любителя як зберігача традиційних або зникаючих культурних форм (Купричев, 2019: 66; Сорокин, 2019: 80; Шматова, 2019: 129-131).

Реалізація творчих здібностей молодих акторів залежить від багатьох факторів, у тому числі соціальних умов, в яких виявляється здатність людини до коректної поведінки з колегами та під час робочого процесу. У сучасних умовах потрібні великі енергетичні, психосоматичні витрати, щоб мобілізувати свою волю і зуміти втілити свої творчі устремління. Нині у цьому відношенні, як і в будь-який інший період історії, $\epsilon$ жорстка конкуренція, так звана «битва культур». Сучасне сценічне мистецтво стрімко розвивається, у ньому широко представлені різні види та жанри: як традиційні, приміром опера, так і нові, що зумовлено саме науково-технічним прогресом (Юдова-Романова, 2017: 245; Юдова-Романова, 2018: 230).

Аналіз досліджень. Мова артиста на сцені підпорядкована суворій ритмічній партитурі, яку задають текст автора, режисер вистави, навіть сценічні і біологічні ритми партнера. Тривалість вистави не $є$ фіксованою величиною. Навіть погане самопочуття артиста часом зрушує темпоритмічні кордони, задані режисером. Тому для артистів театру, хоч вони і прагнуть, незважаючи ні на що існувати на сцені, ні на секунду не забуваючи про свій внутрішній метроном, розтягнутий або зіграний на кілька хвилин раніше спектакль не $\epsilon$ чимось незвичайним (Юй, 2020: 15-16). Головною відмінною рисою будь-якого художника в зрізі культурних пошуків у творчості є здатність фантазувати. Професор Є. Я. Басін охарактеризував цю категорію як синтез уяви і емпатії (перевтілення). Варто відзначити, що «перевтілення» $є$ чи не головним принципом системи Станіславського (Юдова-Романова та ін., 2019: 64).

Якщо звернутись до загальновстановлених правил акторського етикету, то можна визначити декілька правил, які $є$ важливими для створення сценічної культури. Особливо це стосується аматорських колективів. Ось найголовніші пункти за визначенням Сорокіна: пунктуальність, чемна поведінка на репетиціях, вимкнені мобільні телефони, правило утримання від будь-яких пліток, присутність на технічних репетиціях, збереження професіоналізму до останньої хвилини на сцені, готовність до надзвичайних ситуацій, готовність брати на себе додаткові обов'язки, залучення до спільної роботи та вирішення спільних проблем, утримання від алкоголю та нелегальних речовин (Сорокин, 2019: 83).

Мета статті полягає у тому, аби виявити основні проблеми, які можуть виникнути у акторів 3 аматорського колективу під час виступу на сцені, та знайти способи їх вирішення.

Виклад основного матеріалу. Проблема сценічної уваги на перший погляд здається дуже простою. Специфічні умови творчості висувають артисту такі вимоги, виконати які, не володіючи здатністю управляти своєю увагою, не видається можливим. Актор повинен: 
- підпорядковувати свою поведінку вимогам сценічності, пластичності, ритмічності;

- виконувати малюнок мізансцен, встановлений режисером, а також власні творчі завдання;

- вміти узгодити свою поведінку з поведінкою партнерів і з навколишнім середовищем;

- враховувати реакцію залу для глядачів;

- розраховувати кожен свій рух і кожен звук свого голосу, домагаючись в усьому виразності за максимальної економії засобів вираження (Качуринець, 2013: 54).

Встановлюючи необхідність зосередженої уваги на сцені, ми тільки викликаємо цілу низку питань і непорозумінь. Такого стану, за якого увага спить, коли людина не зайнята тим чи іншим об'єктом, не існує. Навіть у ті хвилини, коли ми відпочиваємо і нам здається, що наша увага нічим конкретним не зайнята, вона все ж працює. Увага може бути поверхневою, може швидко переходити 3 одного об'єкта на інший, не зосереджуючись на жодному з них, вона може бути не пов'язана ні 3 якою конкретною метою, але вона буде проявлятися у кожен момент.

Увага може бути довільною і мимовільною. Елементарною (фізичною) формою уваги $\epsilon$ увага мимовільна. Дитина в грудному віці вже має здатність реагувати на зовнішні подразники актом мимовільного зосередження. Коли вона повертає голову до блискучого предмета і фіксує на ньому свій погляд, вона здійснює акт мимовільної уваги. У разі мимовільної уваги не суб' єкт опановує об'єкт, а навпаки, об'єкт приковує до себе увагу суб'єкта. Тому мимовільна увага $є$ одночасно пасивною увагою. Причина її виникнення - в особливих властивостях об' єкта. Новизна або яскравість предмета, його надзвичайний вид, сила, з якою він подразнює органи сприйняття, нарешті, його зв'язок з потребами людини - все це може послужити причиною мимовільного виникнення пасивної орієнтовної реакції, за якої мускулатура рефлекторно (автоматично) пристосовує рецептори (сприймаючі органи) до найкращого сприйняття об'єкта. Таким чином, мимовільна увага здійснюється абсолютно незалежно від свідомих намірів людини.

Довільна увага, навпаки, тісно пов'язана з процесами, що відбуваються в свідомості людини, і носить активний характер. У разі довільної уваги предмет стає об'єктом зосередження не тому (або не тільки тому), що він цікавий сам по собі, а неодмінно у зв'язку з процесами, що відбуваються в свідомості суб'єкта. Об'єкт неминуче включається в процес мислення людини. Зміст безпосередньо даного нам об'єкта у цьому разі вступає в нашій свідомості в різні нові зв'язки, включається в ситуації, в яких його безпосередньо нам ніхто не давав. Тобто довільна (або активна) увага людини завжди виходить за межі безпосередньо даного чуттєвого змісту.

Крім довільної (активної) і мимовільної (пасивної) уваги в їх чистому вигляді, ми постійно стикаємося також 3 переходами однієї форми в іншу. Предмет, який спочатку викликає до себе нашу мимовільну увагу, легко може стати надалі об'єктом активної зосередженості. I навпаки, предмет, з яким ми встановили зв'язок шляхом вольового зосередження на ньому, може стати настільки для нас цікавим, що не буде більше ніякої потреби в зусиллях волі, щоб утримувати увагу, що таким чином 3 довільного перетвориться на мимовільне.

Залежно від характеру об'єкта слід розрізняти увагу зовнішню і внутрішню. Зовнішньою ми будемо називати таку увагу, яка пов'язана 3 об'єктами, що перебувають поза межами відчуття самої людини. Об'єктами зовнішнього уваги, таким чином, можуть бути предмети навколо нас $\mathrm{i}$ звуки. Залежно від того, за допомогою яких органів чуття здійснюється зовнішня увага, вона може бути зоровою, слуховою, відчуттєвою, нюховою і смаковою. Серед цих п'яти видів зовнішньої уваги зорова і слухова $є$ основними, оскільки людині властиво орієнтуватися в навколишньому середовищі головним чином за допомогою зору і слуху.

До числа об'єктів, які незалежно від волі актора або навіть усупереч його волі самі опановують його увагу, належать насамперед глядачі. В руках тих, хто перебуває в залі, - доля актора. Хоча актор і не бачить глядачів, але зал для глядачів живе, дихає, активно або пасивно сприймає спектакль і тим самим неймовірно хвилює актора. Актор ніби лише фізично, зовнішнім чином присутній на сцені - думками і почуттями він весь по інший бік рампи. У міру того як він прислухається до таємничого дихання залу, ним усе сильніше опановує почуття страху; грунт поступово відходить у нього з-під ніг. Актор згадує, що у нього був якийсь творчий задум. Але ось пройшла вже третина відповідальної сцени, а він зовсім не пам'ятає, що робив і що говорив. Тепер він намагається стежити за собою, намагається підпорядкувати сценічну поведінку контролю свідомості, - і тільки тоді об'єктом його уваги стає він сам, його власна поведінка і його власні переживання на сцені.

Поки увага артиста була прикута до залу глядачів, вона була зовнішньою. Тепер вона стала внутрішньою, переключилася на процеси, що відбуваються в його власній свідомості. Зовнішній світ 
тепер як би перестав існувати для актора. Кашляють глядачі або сміються - йому немає до цього діла: він нічого не бачить і не чує. Він не бачить і не чує також і того, що відбувається на сцені. Обличчя партнера плаває в тумані, голос партнера звучить як ніби здалеку, і сенс сказаного ним тексту не доходить до свідомості. Якщо в поле уваги артиста, що перебуває в цьому складному та напруженому стані, і потрапляє іноді партнер, то сприймається він не як персонаж п'єси, стосовно якого слід так чи інакше діяти, а тільки як актор, у деякому роді товариш по нещастю.

Увага артиста мимоволі тяжіє до трьох об'єктів: глядач, сам актор і партнер (але не як образ, а тільки як актор). Навіть досвідчений актор, який добре знає закони мистецтва, перебуваючи на сцені, постійно наражається на небезпеку опинитися в зайвій владі цих об'єктів. Це особливо стосується тих випадків, коли актор змушений тримати серйозний творчий іспит. Наприклад, граючи перший раз відповідальну роль, нерідко i досвідчений актор почувається новачком: так само стискується його серце, напружуються м'язи, дерев'яніє тіло, так само увага його довго не може прикріпитися до потрібного об'єкта. Те ж саме іноді відбувається з досвідченими акторами, коли вони опиняються перед особливо відповідальною для них аудиторією.

Однією з найважливіших для артиста якостей $\epsilon$ уміння встановлювати і змінювати відповідно до завдання свої сценічні відносини. У цій здатності проявляється наївність, безпосередність, а отже, i професійна придатність актора. Не володіючи цією здатністю хоча б у самій зародковій формі, справжнім актором стати не можна. Школа може розвинути, натренувати іï, але прищепити іiї тому, хто від природи зовсім ії позбавлений, вона безсила. Один з найважливіших законів для акторааматора говорить: актор повинен сприймати будьякий об'єкт таким, яким він реально йому дається, а от ставитися до цього об'єкта він повинен так, як йому задано. Це творче перетворення навко- лишнього середовища і всього, що відбувається на сцені, актор здійснює за допомогою своєї творчої віри в правду вимислу, а творча віра видобувається за допомогою фантазії, що поставляє необхідні сценічні виправдання. Таким чином, увага i віра, зцементовані за допомогою низки сценічних виправдань в одне нерозривне ціле, викликають у психіці актора нове ставлення до об'єкта і таким чином перетворюють цей об'єкт, перетворюють його на нову, народжену акторською фантазією сценічну реальність, на художню правду вимислу.

Висновки. На підставі всього, що сказано про природу сценічної уваги, тепер неважко вирішити питання і про основний принцип формування сценічної культури молодого акторського колективу i його поведінки на сцені. Сценічна увага полягає в тому, що актор, зосереджений на даному йому об'єкті, творчо перетворює його. За допомогою фантазії він перетворює об'єкт на те, чого вимагає від нього специфіка втілення образу. Отже, будь-який об'єкт для актора одночасно і те, чим він $\epsilon$ насправді, і те, чим він повинен бути для нього як образу. Для актора-творця він те, що він є. Для акторського образу - те, чим повинен бути. Тому на кожному об'єкті актор зосереджений і як актор-творець, і як актор-образ.

Отже, суб'єктом сценічної уваги актора $\epsilon$ актор-творець і актор-образ одночасно. Безсумнівно, що всі свідомі зусилля актора повинні бути спрямовані на те, щоб його сценічна увага була увагою образу. Рідко акторові доводиться нарікати на себе за те, що він надмірно захопився сценічним об'єктом; незрівнянно частіше він змушений засмучуватися тим, що увага його до об'єкта носить занадто поверхневий, формальний характер. Аби мати змогу зосередитись на своєму образі, на акторському завданні та всьому, що його оточує, актор має знайти свою увагу, відтворити певну послідовність дій, яка допомагає зосередитись у реальному житті. Також важливо віднайти акторську віру у свій образ, своє бачення та здатність перевтілюватись на сцені.

\section{СПИСОК ВИКОРИСТАНИХ ДЖЕРЕЛ}

1. Басалаев С. Н. Системная интерпретация сценического общения. Вестник Томского государственного университета. Культурология и искусствоведение. 2018. № 29. С. 43-62.

2. Качуринець С. Є. Гармонійна єдність творчих надбань аматорських і професійних колективів народно-сценічного танцю України на початку ХХ ст. Актуальні питання мистецької педагогіки. 2013. № 2. С. 54-57.

3. Купричев С. С. Сценическое тело (заметки к «Театральной антропологии» Э. Барбы и Н. Саварезе). Научныци результат. Социальные и гуманитарные исследования. 2019. № 2. С. 60-71.

4. Сорокин В. Н. Актерская компетенция как социокультурный ресурс. Культурное наследие России. 2019. № 1. C. $81-85$.

5. Слуцкая Е. А. Театральный режиссер в эпицентре социальных проблем. Ярославский педагогический вестник. 2019. № 2. C. 158-164.

6. Шматова Г. А. Возможно ли избежать «кривляний» на сцене? О кризисе сценической репрезентации эмоций. Вестник РГГУ. Серия: Литературоведение. Языкознание. Культурология. 2019. № 3. С. 123-137. 
7. Юдова-Романова К. В. Пневматичні засоби конструювання сценічного простору. Вісник Національної академії керівних кадрів культури і мистецтв. 2017. № 4. С. 242-247.

8. Юдова-Романова К. В. Дизайн сценічного простору вогняними засобами конструювання. Вісник Національної академії керівних кадрів культури і мистеиттв. 2018. № 1. С. 228-232.

9. Юдова-Романова К., Стрельчук В., Чубукова Ю. Режисерські інновації у використанні технічних засобів і технологій у сценічному мистецтві. Вісник Київського національного університету культури і мистеитв. 2019. № 2 (1). С. 52-72.

10. Юй Я. Актер и чувство речевой «свободы» на сцене и на экране. Философия и культура. 2020. № 7. С. 10-20.

\section{REFERENCES}

1. Basalaev S. N. Sistemnaya interpretatsiya stsenicheskogo obscheniya [Systematic interpretation of stage communication]. Vestnik Tomskogo gosudarstvennogo universiteta. Kulturologiya i iskusstvovedenie, 2018, No. 29, pp. 43-62 [in Russian].

2. Kachurynets S. Ye. Harmoniina yednist tvorchykh nadban amatorskykh i profesiinykh kolektyviv narodno-stsenichnoho tantsiu Ukrainy na pochatku XX st. [Harmonious unity of creative achievements of amateur and professional groups of folk stage dance of Ukraine in the early XX century]. Aktualni pytannia mystetskoi pedahohik, 2013, No. 2, pp. 54-57 [in Ukrainian].

3. Kuprichev S. S. Stsenicheskoe telo (zametki k "Teatralnoy antropologii” E. Barbyi i N. Savareze) [Stage body (notes to "Theatrical Anthropology" by E. Barba and N. Savarese]. Nauchnyiy rezultat. Sotsialnyie i gumanitarnyie issledovaniya, 2019, No. 2, pp. 60-71 [in Russian].

4. Sorokin V. N. Akterskaya kompetentsiya kak sotsiokulturnyiy resurs [Acting competence as a socio-cultural resource]. Kulturnoe nasledie Rossii, 2019, No. 1, pp. 81-85 [in Russian].

5. Slutskaya E. A. Teatralnyiy rezhisser v epitsentre sotsialnyih problem [Theatrical director at the epicenter of social problems]. Yaroslavskiy pedagogicheskiy vestnik, 2019, No. 2, pp. 158-164 [in Russian].

6. Shmatova G. A. Vozmozhno li izbezhat "krivlyaniy" na stsene? O krizise stsenicheskoy reprezentatsii emotsiy [Is it possible to avoid "twists" on stage? About the crisis of stage representation of emotions]. Vestnik RGGU. Seriya: Literaturovedenie. Yazyikoznanie. Kulturologiya, 2019, No. 3, pp. 123-137 [in Russian].

7. Yudova-Romanova K. V. Pnevmatychni zasoby konstruiuvannia stsenichnoho prostoru [Pneumatic means of designing stage space]. Visnyk Natsionalnoi akademii kerivnykh kadriv kultury i mystetstv, 2017, No. 4, pp. 242-247 [in Ukrainian].

8. Yudova-Romanova K. V. Dyzain stsenichnoho prostoru vohnianymy zasobamy konstruiuvannia [Design of stage space by fiery means of construction]. Visnyk Natsionalnoi akademii kerivnykh kadriv kultury i mystetstv, 2018, No. 1, pp. 228-232 [in Ukrainian].

9. Yudova-Romanova K., Strelchuk V., Chubukova Yu. Rezhyserski innovatsii u vykorystanni tekhnichnykh zasobiv i tekhnolohii u stsenichnomu mystetstvi [Directing innovations in the use of technical means and technologies in the performing arts]. Visnyk Kyivskoho natsionalnoho universytetu kultury i mystetstv, 2019, No. 2 (1), pp. 52-72 [in Ukrainian].

10. Yuy Ya. Akter i chuvstvo rechevoy "svobody" na stsene i na ekrane [Actor and the feeling of speech "freedom" on stage and on the screen]. Filosofiya i kultura, 2020, No. 7, pp. 10-20 [in Russian]. 